\title{
REFINEMENTS, EXTENSIONS AND GENERALIZATIONS OF THE SECOND KERSHAW'S DOUBLE INEQUALITY
}

\author{
Feng QI, XiaO-Ai Li And Shou-Xin Chen
}

Abstract. In the paper, the second Kershaw's double inequality concerning the ratio of two gamma functions is refined, extended and generalized elegantly.

Mathematics subject classification (2000): 26A48, 26A51, 26D20, 33B10, 33B15, 65R10.

Key words and phrases: Kershaw's double inequality, refinement, extension, generalization, generalized logarithmic mean, ratio of two gamma functions, psi function, polygamma function, inequality, monotonicity.

\section{REFERENCES}

[1] M. Abramowitz And I. A. Stegun (EDS), Handbook of Mathematical Functions with Formulas, Graphs, and Mathematical Tables, National Bureau of Standards, Applied Mathematics Series 55, 9th printing, Washington, 1970.

[2] N. BATIR, On some properties of digamma and polygamma functions, J. Math. Anal. Appl. 328 (2007), no. 1, 452-465.

[3] C. BERG, Integral representation of some functions related to the gamma function, Mediterr. J. Math. 1 (2004), no. 4, 433-439.

[4] P. S. Bullen, Handbook of Means and Their Inequalities, Mathematics and its Applications, Volume 560, Kluwer Academic Publishers, Dordrecht/Boston/London, 2003.

[5] J. Bustoz And M. E. H. IsmaIL, On gamma function inequalities, Math. Comp. 47 (1986), 659-667.

[6] G. T. CARGo, Comparable means and generalized convexity, J. Math. Anal. Appl. 12 (1965), 387-392.

[7] CH.-P. CHEN, Monotonicity and convexity for the gamma function, J. Inequal. Pure Appl. Math. 6 (2005), no. 4, Art. 100; Available online at URL: http://jipam.vu.edu .au/article.php? sid=574.

[8] CH.-P. CHEN AND F. QI, An alternative proof of monotonicity for the extended mean values, Austral. J. Math. Anal. Appl. 1 (2004), no. 2, Art. 11; Available online at URL: http: //ajmaa.org/cgi-bin/paper.pl?string=v1n2/V1I2P11. tex.

[9] N. Elezović, C. GIORdANO AND J. PEČARIĆ, The best bounds in Gautschi's inequality, Math. Inequal. Appl. 3 (2000), 239-252.

[10] T. ERBER, The gamma function inequalities of Gurland and Gautschi, Scand. Actuar. J. 1960 (1961), $27-28$.

[11] W. GAUTSCHI, Some elementary inequalities relating to the gamma and incomplete gamma function, J. Math. Phys. 38 (1959), no. 1, 77-81.

[12] J. D. KEČKIĆ AND P. M. VASIĆ, Some inequalities for the gamma function, Publ. Inst. Math. (Beograd) (N. S.) 11 (1971), 107-114.

[13] D. KERSHAW, Some extensions of W. Gautschi's inequalities for the gamma function, Math. Comp. 41 (1983), no. 164, 607-611.

[14] A. LAFORGIA, Further inequalities for the gamma function, Math. Comp. 42 (1984), no. 166, 597-600.

[15] E. B. LEACH AND M. C. Sholander, Extended mean values, Amer. Math. Monthly 85 (1978), 84-90.

[16] E. B. LEACH AND M. C. SHOLANDER, Extended mean values II, J. Math. Anal. Appl. 92 (1983), $207-223$.

[17] Z. PÁLES, Inequalities for differences of powers, J. Math. Anal. Appl. 131 (1988), 271-281.

[18] J. E. PEČARIĆ, F. QI, V. ŠIMIĆ AND S.-L. XU, Refinements and extensions of an inequality, III, J. Math. Anal. Appl. 227 (1998), no. 2, 439-448. 
[19] F. QI, A class of logarithmically completely monotonic functions and application to the best bounds in the second Gautschi-Kershaw's inequality, J. Comput. Appl. Math. (2009), in press, Available online at URL: http://dx.doi.org/10.1016/j.cam.2008.05.030. RGMIA Res. Rep. Coll. 9 (2006), no. 4, Art. 11; Available online at URL: http://www. staff.vu.edu.au/rgmia/v9n4 .asp.

[20] F. QI, A class of logarithmically completely monotonic functions and the best bounds in the first Kershaw's double inequality, J. Comput. Appl. Math. 206 (2007), no. 2, 1007-1014; Available online at URL: http://dx.doi.org/10.1016/j.cam.2006.09.005.RGMIA Res. Rep. Coll. 9 (2006), no. 2, Art. 16, 351-362; Available online at URL: http: //www. staff.vu .edu .au/rgmia/v9n2 .asp.

[21] F. QI, A completely monotonic function involving divided difference of psi function and an equivalent inequality involving sum, ANZIAM J. 48 (2007), no. 4, 523-532. RGMIA Res. Rep. Coll. 9 (2006), no. 4, Art. 5; Available online at URL: http: / /www. staff.vu.edu.au/rgmia/v9n4 .asp.

[22] F. QI, A completely monotonic function involving divided differences of psi and polygamma functions and an application, RGMIA Res. Rep. Coll. 9 (2006), no. 4, Art. 8; Available online at URL: http://www.staff.vu.edu.au/rgmia/v9n4.asp.

[23] F. QI, A new lower bound in the second Kershaw's double inequality, J. Comput. Appl. Math. 214 (2008), no. 2. 610-616; Available online at URL: http://dx.doi.org/10.1016/j.cam.2007.03.016. RGMIA Res. Rep. Coll. 10 (2007), no. 1, Art. 9; Available online at $U R L$ : 
http: / /www.staff.vu.edu.au/rgmia/v10n1.asp.

[24] F. QI, A note on Schur-convexity of extended mean values, Rocky Mountain J. Math. 35 (2005), no. 5, 1787-1793.

[25] F. QI, Certain logarithmically $N$-alternating monotonic functions involving gamma and $q$-gamma functions, Nonlinear Funct. Anal. Appl. 12 (2007), no. 4, 675-685; RGMIA Res. Rep. Coll. 8 (2005), no. 3, Art. 5, 413-422; Available online at URL: http: / /www.staff.vu.edu .au/rgmia/v8n3 .asp.

[26] F. QI, Generalized abstracted mean values, J. Inequal. Pure Appl. Math. 1 (2000), no. 1, Art. 4; Available online at URL: http: / / j ipam.vu.edu . au/article.php? sid=97. RGMIA Res. Rep. Coll. 2 (1999), no. 5, Art. 4, 633-642; Available online at URL: http: / /www . staff.vu. edu .au/rgmia/v2n5 . asp.

[27] F. QI, Generalized weighted mean values with two parameters, R. Soc. Lond. Proc. Ser. A Math. Phys. Eng. Sci. 454 (1998), no. 1978, 2723-2732.

[28] F. QI, Logarithmic convexity of extended mean values, Proc. Amer. Math. Soc. 130 (2002), no. 6, 1787-1796.

[29] F. QI, Logarithmic convexities of the extended mean values, RGMIA Res. Rep. Coll. 2 (1999), no. 5, Art. 5, 643-652; Available online at URL: http: //www.staff.vu.edu.au/rgmia/v2n5 .asp.

[30] F. QI, Monotonicity results and inequalities for the gamma and incomplete gamma functions, Math. Inequal. Appl. 5 (2002), no. 1, 61-67. RGMIA Res. Rep. Coll. 2 (1999), no. 7, Art. 7, 1027-1034; Available online at URL: http://www.staff.vu.edu.au/rgmia/v2n7.asp.

[31] F. QI, Schur-convexity of the extended mean values, RGMIA Res. Rep. Coll. 4 (2001), no. 4, Art. 4, 529-533; Available online at URL: http: //www.staff.vu.edu .au/rgmia/v4n4 .asp.

[32] F. QI, The best bounds in Kershaw's inequality and two completely monotonic functions, RGMIA Res. Rep. Coll. 9 (2006), no. 4, Art. 2; Available online at URL:

http: //www.staff.vu.edu.au/rgmia/v9n4.asp.

[33] F. QI, The extended mean values: Definition, properties, monotonicities, comparison, convexities, generalizations, and applications, Cubo Mat. Educ. 5 (2003), no. 3, 63-90. RGMIA Res. Rep. Coll. 5 (2002), no. 1, Art. 5, 57-80; Available online at URL: http://www. staff.vu . edu .au/rgmia/v5n1.asp.

[34] F. QI, Three classes of logarithmically completely monotonic functions involving gamma and psi functions, Integral Transforms Spec. Funct. 18 (2007), no. 7, 503-509; Available online at URL: http://dx.doi.org/10.1080/10652460701358976. RGMIA Res. Rep. Coll. 9 (2006), Suppl., Art. 6; Available online at URL: http: //www. staff.vu.edu.au/rgmia/v9 (E) . asp.

[35] F. QI, J. CAO, AND D.-W. NIU, Four logarithmically completely monotonic functions involving gamma function and originating from problems of traffic flow, RGMIA Res. Rep. Coll. 9 (2006), no. 3, Art 9; Available online at URL: http://www.staff.vu.edu.au/rgmia/v9n3.asp.

[36] F. QI, D.-W. NIU, J. CAO, AND SH.-X. CHEN, Four logarithmically completely monotonic functions involving gamma function, J. Korean Math. Soc. 45 (2008), no. 2, 559-573.

[37] F. QI AND B.-N. GUO, A class of logarithmically completely monotonic functions and the best bounds in the second Kershaw's double inequality, J. Comput. Appl. Math. 212 (2008) no. 2, 444-456; Available online at URL: http://dx.doi.org/10.1016/j.cam.2006.12.022. RGMIA Res. Rep. Coll. 10 (2007), no. 2, Art. 5; Available online at URL: http: / /www. staff . vu .edu .au/rgmia/v10n2 .asp.

[38] F. QI AND B.-N. GuO, On Steffensen pairs, J. Math. Anal. Appl. 271 (2002), no. 2, 534541. RGMIA Res. Rep. Coll. 3 (2000), no. 3, Art. 10, 425-430; Available online at URL: http://www.staff.vu.edu.au/rgmia/v3n3.asp.

[39] F. QI AND B.-N. GUO, Wendel-Gautschi-Kershaw's inequalities and sufficient and necessary conditions that a class of functions involving ratio of gamma functions are logarithmically completely monotonic, RGMIA Res. Rep. Coll. 10 (2007), no. 1, Art 2; Available online at URL: http: / /www.staff.vu.edu.au/rgmia/v10n1.asp.

[40] F. QI, B.-N. GuO, AND CH.-P. CHEN, The best bounds in Gautschi-Kershaw inequalities, Math. Inequal. Appl. 9 (2006), no. 3, 427-436. RGMIA Res. Rep. Coll. 8 (2005), no. 2, Art. 17, 311-320; Available online at URL: http: //www.staff.vu.edu.au/rgmia/v8n2 .asp.

[41] F. QI AND S. GUO, New upper bounds in the second Kershaw's double inequality and its generalizations, RGMIA Res. Rep. Coll. 10 (2007), no. 2, Art. 1; Available online at URL:

http: //www.staff.vu.edu.au/rgmia/v10n2.asp.

[42] F. QI, S. GUO AND SH.-X. CHEN, A new upper bound in the second Kershaw's double inequality and its generalizations, J. Comput. Appl. Math. (2008), in press; Available online at URL: http://dx.doi.org/10.1016/j.cam.2007.07.037.

[43] F. QI, S. GUO AND B.-N. GUO, Note on a class of completely monotonic functions involving the polygamma functions. RGMIA Res. Rep. Coll. 10 (2007), no. 1, Art. 5; Available online at URL: http: / / www.staff.vu.edu.au/rgmia/v10n1.asp.

[44] F. QI AND Q.-M. LUO, A simple proof of monotonicity for extended mean values, J. Math. Anal. Appl. 224 (1998), no. 2, 356-359. 
[45] F. QI, J. SÁNDOR, S. S. DRAGOMIR, AND A. SOFO, Notes on the Schur-convexity of the extended mean values, Taiwanese J. Math. 9 (2005), no. 3, 411-420. RGMIA Res. Rep. Coll. 5 (2002), no. 1, Art. 3 , 19-27; Available online at URL: http://www. staff.vu.edu.au/rgmia/v5n1.asp.

[46] F. QI AND S.-L. XU, The function $\left(b^{x}-a^{x}\right) / x$ : Inequalities and properties, Proc. Amer. Math. Soc. 126 (1998), no. 11, 3355-3359.

[47] F. QI, S.-L. XU, AND L. DEBNATH, A new proof of monotonicity for extended mean values, Internat. J. Math. Math. Sci. 22 (1999), no. 2, 415-420.

[48] F. QI AND SH.-Q. ZHANG, Note on monotonicity of generalized weighted mean values, R. Soc. Lond. Proc. Ser. A Math. Phys. Eng. Sci. 455 (1999), no. 1989, 3259-3260.

[49] H.-N. SHI, SH.-H. WU, AND F. QI, An alternative note on the Schur-convexity of the extended mean values, Math. Inequal. Appl. 9 (2006), no. 2, 219-224. Bùděngshì Yānjiū Tōngxùn (Communications in Studies on Inequalities) 12 (2005), no. 3, 251-257.

[50] J. G. WENDEL, Note on the gamma function, Amer. Math. Monthly 55 (1948), no. 9, 563-564.

[51] D. V. WIDDER, The Laplace Transform, Princeton University Press, Princeton, 1946.

[52] A. WitKowski, Convexity of weighted extended mean values, RGMIA Res. Rep. Coll. 7 (2004), no. 2, Art. 10; Available online at URL: http://www. staff.vu.edu .au/rgmia/v7n2 .asp.

[53] A. WitKowsKI, Weighted extended mean values, Colloq. Math. 100 (2004), no. 1, 111-117. RGMIA Res. Rep. Coll. 7 (2004), no. 1, Art. 6; Available online at URL: http://www.staff.vu.edu.au/rgmia/v7n1.asp.

[54] S.-L. ZhANG, CH.-P. CHEN AND F. QI, Another proof of monotonicity for the extended mean values, Tamkang J. Math. 37 (2006), no. 3, 207-209. 